\title{
Effects of zinc and nitrogen fertilizer and their application method on yield and yield components of Phaseolus vulgaris L.
}

\author{
Faizus Salehin ${ }^{1 *}$, Shahedur Rahman ${ }^{2}$ \\ ${ }^{1}$ Department of Biotechnology and Genetic Engineering, University of Development Alternative, Dhaka, Bangladesh; \\ *Corresponding Author: faizus1212@gmail.com \\ ${ }^{2}$ Department of Genetic Engineering and Biotechnology, Jessore Science and Technology University, Jessore, Bangladesh
}

Received 6 September 2011; revised 18 November 2011; accepted 16 December 2011

\begin{abstract}
An experiment in factorial format based on randomized complete block design with 3 replications was conducted to study the effects of zinc spray ( 0 and $1 \mathrm{~g} / \mathrm{L}$ ) and nitrogen fertilizer ( 0 , 25,50 and $75 \mathrm{~kg} / \mathrm{ha}$ pure nitrogen) on yield and yield components of Phaseolus vulgaris. In maturity time, seed yield, 100 seed weight, number of pods per plant, number of seeds per pod and plant height were measured. Results showed that, use of zinc spray had a significant effect in $1 \%$ probability level on all measured traits. Also, the effect of nitrogen on all studied traits was significant in $1 \%$ probability level. Interaction effect of zinc spray and nitrogen fertilizer on number of seed per pod in $1 \%$ and on seed yield and plant height in $5 \%$ was significant and on other traits was non significant. The highest seed yield was obtained by zinc spray application with $1996 \mathrm{~kg} / \mathrm{ha}$. Among nitrogen fertilizer levels, use of $90 \mathrm{~kg} / \mathrm{ha}$ pure nitrogen showed highest seed yield.
\end{abstract}

Keywords: Phaseolus vulgaris; Zinc Spray; Nitrogen Fertilizer

\section{INTRODUCTION}

Phaseolus vulgaris L. is one of the most important leguminous crops for exportation and consumption [1]. Nitrogen $(\mathrm{N})$ fertilizer played a significant role in increase of crop yield [2]. Nitrogen deficiency generally results in stunted growth and chlorotic leaves caused by poor assimilate formation that leads to premature flowering and shortening of the growth cycle [3]. Limitation of nitrogen in any phase of the plant growth, causes reduction in yield [4]. Abdzad Gohari and Amiri was re- ported that nitrogen fertilization had a positive and significant effect on seed yield, seed weight, number of pods per plant and number of seeds per plant [5].

Seventy years ago, zinc was recognized as an essential micronutrient [6], and its deficiency in agricultural crops is one of the most common micronutrient deficiencies [7]. Zinc deficient soils have been widely found in India, USA, Canada, New Zealand, Africa, Europe and South America [8]. On the other hand, World Health Organization (WHO) reported that human population of developing countries faced with the deficiencies of zinc. Zn deficiency of human is the fifth major cause of diseases and deaths in these countries [9]. Foliar fertilization has the advantage of low application rates, uniform distribution of fertilizer materials and quick responses to applied nutrients. Moreover, hidden hungers can easily be managed [10]. Mahady [11] found that foliar application of $\mathrm{ZnSO}_{4}$ for faba bean plants increased number of pods/plant and seed yield. Ali and Mowafy reported that application of foliar spray with Zn (2\%) slightly improved groundnut yield and it's attributed as well as quality [12]. Thalooth et al. indicated that foliar spraying with $\mathrm{Zn}$ had a positive effect on yield and yield attributes of sunflower plants $[13,14]$.

The aim of the study is to investigate the influences of zinc spray and different amounts of nitrogen fertilizer on yield and the yield components of Phaseolus vulgaris L.

\section{MATERIALS AND METHODS}

In order to investigation of zinc spray and nitrogen fertilizer on yield and yield components of Phaseolus vulgaris $\mathrm{L}$. an experiment in factorial format based on randomized complete block design with 3 replications. Soil analysis results show that (Table 1), the soil texture was loam clay and $\mathrm{pH}$ 7.3. Factors of experiment was included two levels of zinc spraying $\left(\mathrm{z}_{1}\right.$ : without zinc spraying, $\mathrm{z}_{2}$ : zinc spraying $1 \mathrm{~g} / \mathrm{L}$ ) and nitrogen fertilizer $\left(\mathrm{n}_{1}\right.$ : control (without nitrogen fertilizer application), $\mathrm{n}_{2}$ : 
25, $\mathrm{n}_{3}: 50$ and $\mathrm{n}_{4}: 75 \mathrm{~kg} / \mathrm{ha}$ pure nitrogen). Pure nitrogen was prepared from urea (46\% pure nitrogen). Zinc spraying was done in two stages vegetative stage (35 days after sowing) and flowering period. Measured traits were seed yield, seed weight, number of pods per plant, number of seeds per pod and plant height. The data was analyzed using MSTATC software. The Duncan's multiple range tests (DMRT) was used to compare the means at $5 \%$ of significant.

\section{RESULTS AND DISCUSSION}

Results of variance analysis (Table 2) showed that, the effect of zinc spraying on all measured traits had significant differences in $1 \%$ probability level. In all studied traits observed that, use of zinc spraying had an optimum effect on bean characteristics. Comparison of mean showed that the highest seed yield with $1996.1 \mathrm{~kg} / \mathrm{ha}$, 100 seed weight with $43.9 \mathrm{~g}$, number of pods per plant with 7.8, number of seeds per plant with 5.7 and plant height with $84.7 \mathrm{~cm}$ was obtained by zinc spraying (Table 3 ). The lowest seed yield, 100 seed weight, number of pods per plant, number of seeds per pod and plant height respectively with $1730.6 \mathrm{~kg} / \mathrm{ha}, 42.2 \mathrm{~g}, 7.1,4.8$ and $83 \mathrm{~cm}$ was found from without use of zinc spraying. Similar results were reported by Khampariva, Agrawal et al. and Togay et al. [15-17].

With attention to variance analysis results, the effect of nitrogen fertilizer doses on all studied traits was significant in $1 \%$ probability level. Comparison of mean between nitrogen fertilizer levels (Table 3) show that, the highest seed yield, 100 seed weight, number of pods per plant, number of seed per pod and plant height was ob-

Table 1. Soil analysis results of the experimental sites.

\begin{tabular}{cccc}
\hline Depth & $0-30 \mathrm{~cm}$ & Soil texture & Loam clay \\
\hline Clay (\%) & 46.58 & E.C. (mmhos/cm) & 1.32 \\
Silt (\%) & 29.97 & Total nitrogen (\%) & 0.194 \\
Sand (\%) & 23.45 & P (ppm) & 9.1 \\
pH & 7.2 & K (ppm) & 197 \\
\hline
\end{tabular}

Table 2. Analysis of variance related to the traits of pinto bean under different levels of zinc spraying and nitrogen fertilizer.

\begin{tabular}{|c|c|c|c|c|c|c|}
\hline Source of variance & df & Seed yield (kg/ha) & 100 seed weight (g) & No. of pod per plant & No. of seed per pod & Plant height $(\mathrm{cm})$ \\
\hline Zinc spraying (z) & 1 & $400675.042^{* *}$ & $4.084^{* *}$ & $3.219^{* *}$ & $6.966^{* *}$ & $17.528^{* *}$ \\
\hline Nitrogen (n) & 3 & $3718435.042^{* *}$ & $31.032^{* *}$ & $1.023^{* *}$ & $2.688^{* *}$ & $56.144^{* *}$ \\
\hline $\mathrm{Z} \times \mathrm{N}$ & 3 & $22129.486^{*}$ & $0.175^{\text {ns }}$ & $0.163^{* *}$ & $0.184^{\text {ns }}$ & $2.402^{*}$ \\
\hline Error & 14 & 6462.143 & 0.189 & 0.025 & 0.184 & 0.669 \\
\hline
\end{tabular}

ns ${ }^{* *}$ and ${ }^{*}$ respectively: non significant, significant in $1 \%$ and $5 \%$ area.

Table 3. Comparison of the mean of the effects zinc spraying and nitrogen fertilizer.

\begin{tabular}{|c|c|c|c|c|c|}
\hline Treatment & Seed yield (kg/ha) & 100 seed weight (g) & No. of pod per plant & No. of seed per pod & Plant height (cm) \\
\hline \multicolumn{6}{|l|}{ Zinc spraying } \\
\hline $\mathrm{Z}_{1}$ & $1730.6 \mathrm{~b}$ & $42.2 b$ & $7.1 \mathrm{~b}$ & $4.8 \mathrm{~b}$ & $83 b$ \\
\hline $\mathrm{Z}_{2}$ & 1996.1a & 43.9a & $7.8 \mathrm{a}$ & $5.7 \mathrm{a}$ & $84.7 \mathrm{a}$ \\
\hline \multicolumn{6}{|l|}{ Nitrogen } \\
\hline $\mathrm{N}_{1}$ & 933.2d & $39.60 \mathrm{c}$ & $7.115 \mathrm{~d}$ & $4.538 c$ & $81.08 \mathrm{~d}$ \\
\hline $\mathrm{N}_{2}$ & $1539 c$ & $42.99 b$ & $7.328 \mathrm{c}$ & $5.167 b$ & $84 c$ \\
\hline $\mathrm{N}_{3}$ & $2247 b$ & $44.30 \mathrm{a}$ & 7.753b & $5.608 a b$ & $86.03 \mathrm{~b}$ \\
\hline $\mathrm{N}_{4}$ & $2726 a$ & $44.54 a$ & $8.041 \mathrm{a}$ & $6.115 a$ & $88.28 \mathrm{a}$ \\
\hline
\end{tabular}


tained by $75 \mathrm{~kg} /$ ha pure nitrogen respectively with 2724 $\mathrm{kg} / \mathrm{ha}, 44.54 \mathrm{~g}, 8.041,6.11$ and $88.28 \mathrm{~cm}$. the $\mathrm{n}_{3}$ level (50 $\mathrm{kg} /$ ha pure nitrogen) with 44.30 gram 100 seed weight placed in same statistically level with $\mathrm{n}_{4}$ treatment (75 $\mathrm{kg} / \mathrm{ha}$ pure nitrogen). In the other hand the lowest seed yield with $933.2 \mathrm{~kg} / \mathrm{ha}, 100$ seed weight with $39.60 \mathrm{~g}$, number of pods per plant with 7.11, number of seeds per pod with 4.53 and plant height with $81.08 \mathrm{~cm}$ was found from $n_{1}$ treatment (without nitrogen fertilizer application). Similar results were reported by Geetha and Varughese, Mirjana et al. and Abdzad Gohari et al. [18-20].
Interaction effect of zinc spraying and nitrogen fertilizer on number of pods per plant in $1 \%$ and on seed yield and plant height in 5\% probability level was significant. But had not any significant effect on 100 seed weight and number of seeds per pod (Table 2). The highest seed yield with $2771 \mathrm{~kg} / \mathrm{ha}$, plant height with $88.45 \mathrm{~cm}$ and number of pods per plant with 8.57 was obtained by use of zinc spraying and $75 \mathrm{~kg} / \mathrm{ha}$ pure nitrogen application (Figures 1-3). On the other hand, the lowest seed yield with $747.3 \mathrm{~kg} / \mathrm{ha}$, plant height with $79.4 \mathrm{~cm}$ and number of pods per plant with 6.95 was found from $\mathrm{z}_{1} \mathrm{n}_{1}$ treat-

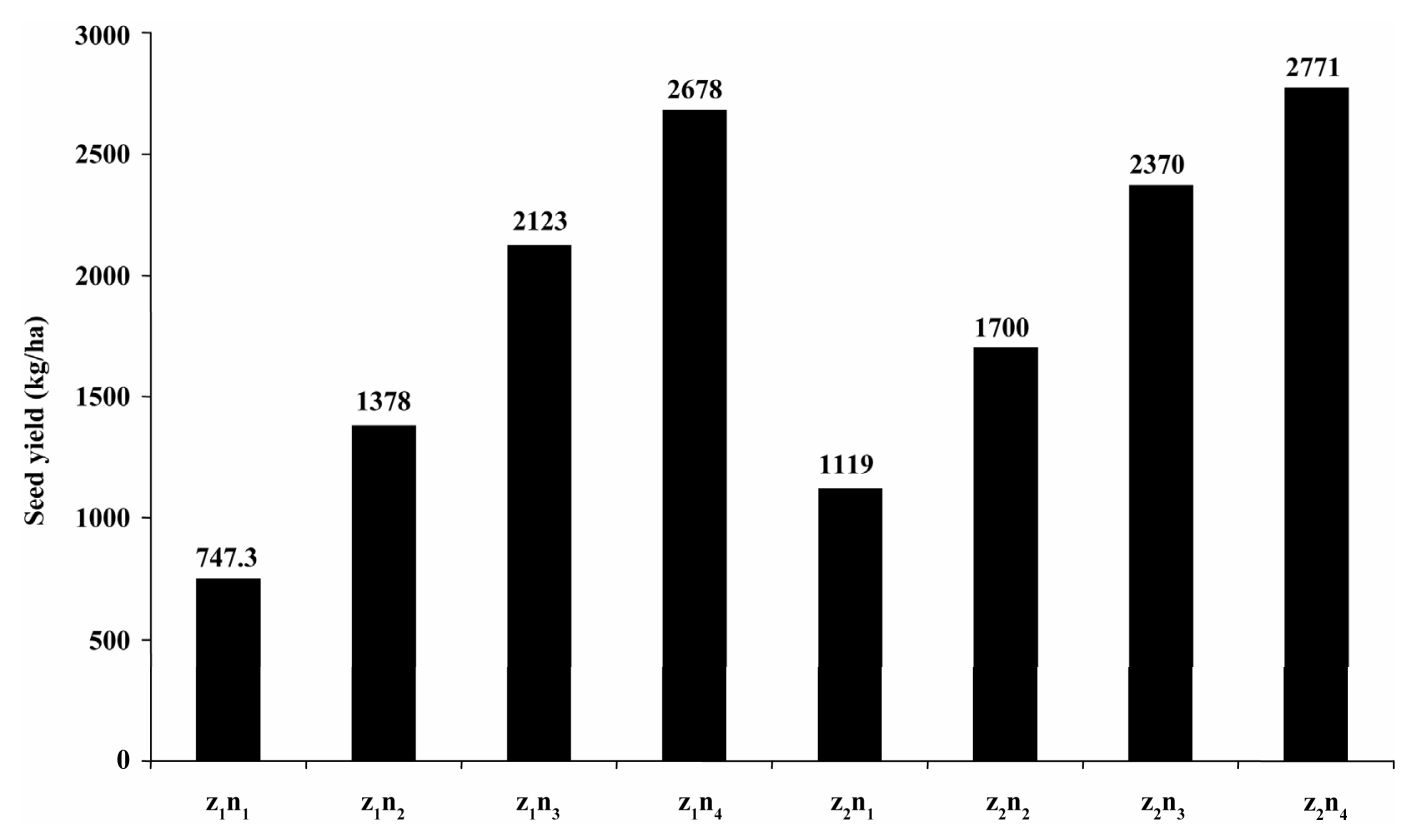

Figure 1. Interaction effect of zinc spraying and nitrogen fertilizer levels on seed yield.

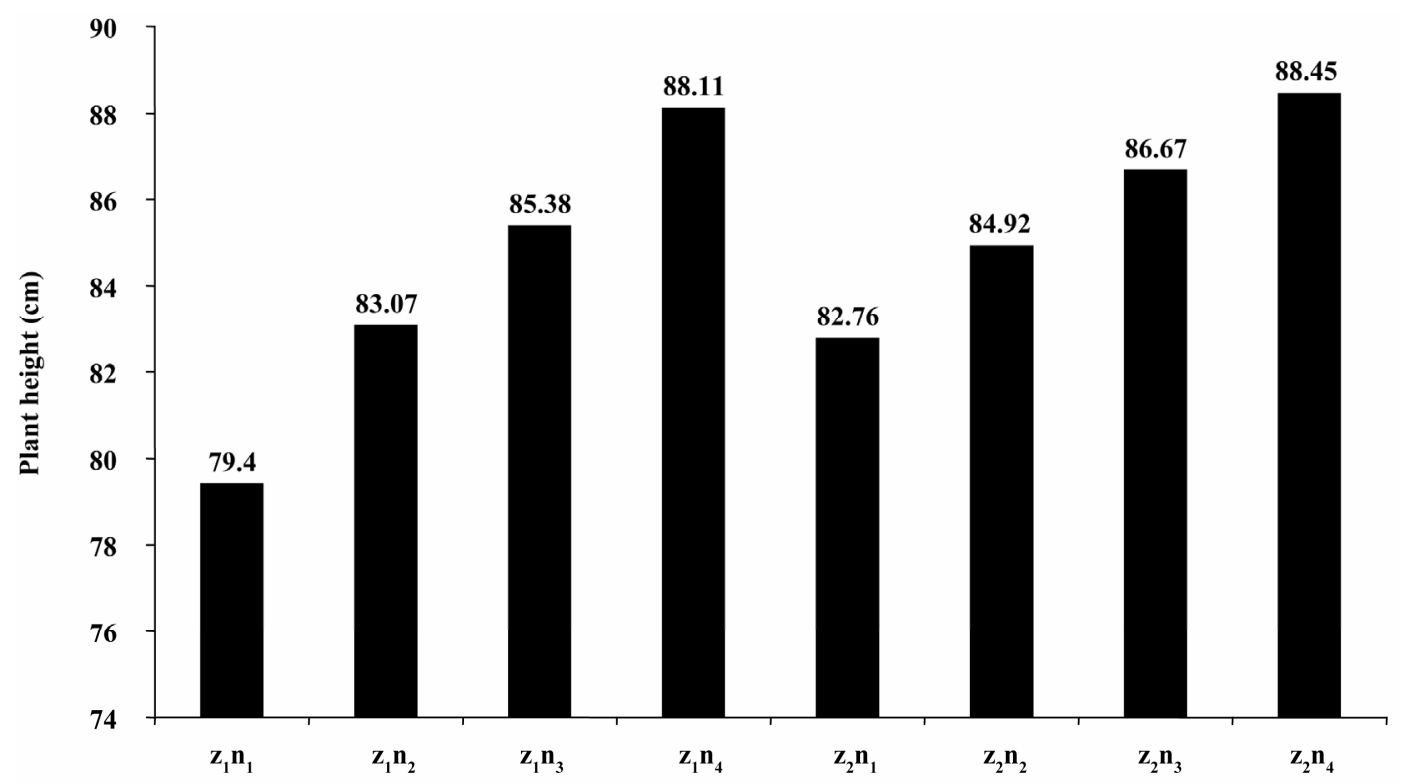

Figure 2. Interaction effect of zinc spraying and nitrogen fertilizer levels on plant height. 


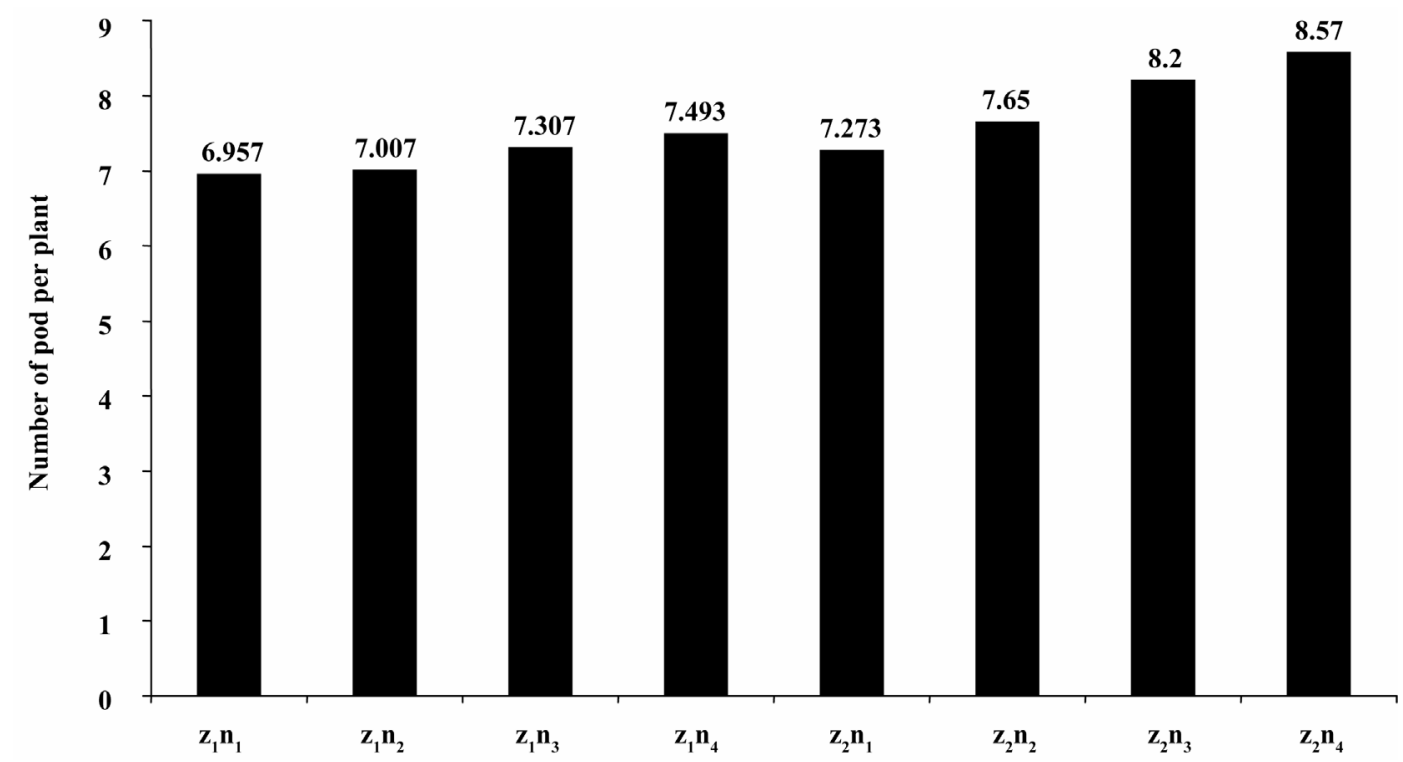

Figure 3. Interaction effect of zinc spraying and nitrogen fertilizer levels on number of pod per plant.

ment (without zinc spraying and no nitrogen fertilizer application). Similar results were obtained by other researcher [20-22].

\section{REFERENCES}

[1] Koocheki, A. and Banayan Aval, M.M. (2004) Pulse crops. Jahad Mashhad Publication, Iran.

[2] Modhej, A., Naderi, A., Emam, Y., Aynehband, A. and Normohamadi, Gh. (2008) Effects of post-anthesis heat stress and nitrogen levels on grain yield in wheat ( $T$. $d u-$ rum and T. aestivum) genotypes. International Journal of Plant Production, 2, 257-267.

[3] Lincoln, T. and Edvardo, Z. (2006) Assimilation of mineral nutrition. In: Plant Physiology (4th Edition), Sinaur Associates, Inc. Pub. Sunderland, 705 pages.

[4] Mohammadian, M. (2002) Final report of research project: Evaluation of nitrogen application in different N-supplying capacity soils on rice yield. Rice Research Institute of Iran.

[5] Abdzad Gohari, A. and Amiri, E. (2010) Increase of bean production in iron and nitrogen fertilization in sustainable agriculture. First National Congress of Sustainable Agriculture and Health Crop Production, Isfahan, 230-236.

[6] Sommer, A.L. and Lipman, C.B. (1996) Evidence on the indispensable nature of zinc and boron for higher green plant. Plant Physiology, 1, 231-249. doi:10.1104/pp.1.3.231

[7] Gupta, U.C. (1989) Effect of zinc fertilization on plant zinc concentration of forages and cereals. Canadian Journal of Soil Science, 69, 473-479. doi:10.4141/cjss89-049

[8] Pedersen, P.E. (1966) Zinc, an overlooked nutrient. Agricultural Chemistry, January 1966, 26-27.

[9] World Health Organization (2002) World health report
2002: Reducing risks, promoting healthy life, Geneva.

[10] Umer, S., Bansal, S.K., Imas, P. and Magen, H. (1999) Effect of foliar fertilization of potassium on yield, quality and nutrient uptake of groundnut. Journal of Plant Nutrition, 22, 1785-1795. doi:10.1080/01904169909365754

[11] Mahady, A.E.M. (1990) Effect of phosphorus fertilizer, some micronutrients and plant density on growth and yield of broad beans. Ph.D. Thesis, Faculty of Agriculture, Moshtohor, Zagazig University, Egypt.

[12] Ali, A.A.G. and Mowafy, S.A.E. (2003) Effect of different levels of potassium and phosphorus fertilizers with the foliar application of zinc and boron on peanut in sandy soils. Zagazig Journal of Agricultural Research, 30, 335-358.

[13] Thalooth, A.T., Badr, N.M. and Mohamed, M.H. (2005) Effect of foliar spraying with $\mathrm{Zn}$ and different levels of Phosphatic fertilizer on growth and yield of sunflower plants grown under saline condition. Egyptian Journal of Agronomy, 27, 11-22.

[14] Valencianoa J.B., Miguélez-Fradeb, M.M., Marcelob, V. and Reinoso, B. (2007) Response of irrigated common bean (Phaseolus vulgaris) yield to foliar zinc application in Spain. New Zealand Journal of Crop and Horticultural Science, 35, 325-330. doi:10.1080/01140670709510198

[15] Khampariva, N.K. (1996) Yield and yield attributing characters of soybean as affected by levels of phosphorous and zinc and their interactions on vertisoil. Crop Research Hisar, 12, 275-282.

[16] Agrawal, V.K., Dwivedi, S.K. and Patal, R.S. (1996) Effect of phosphorus and zinc application on morphological strurctural yield components and seed yield in soybean. Crop Research Hisar, 12, 196-199.

[17] Togay, N., Ciftci, V. and Togay, Y. (2004) the effects of zinc fertilization on yield and some yield components of dry bean (phaseolus vulgaris L.). Asian Journal of Plant 
Sciences, 3, 701-704.

doi:10.3923/ajps.2004.701.704

[18] Geetha, V. and Varughese, K. (2001) Response of vegetable cowpea to nitrogen and potassium under varying methods of irrigation. College of Agriculture, Vellayani 695522, Trivandrum, India, Journal of Tropical Agriculture, 39, 111-113.

[19] Mirjana, J., Zdravkovic, M., Simonida, D. and Damjanovic, M. (2006) Response of beans to inoculation and fertilizers. Annals of the Faculty of Engineering Hunedoara, 5, Revolutiei, 331128, Hunedoara.

[20] Abdzad Gohari, A., Amiri, E., Porrahm Gohari, M. and Bahari, B. (2010) Nitrogen and potassium fertilizer man- agement on yield and yield components of bean in sustainable agriculture condition. First national congress of sustainable agriculture and health crop production. Isfahan, Iran, 246-250.

[21] Koli, B.D., Akashe, V.B. and Shaikh, A.A. (1996) Effect of row spacing, plant density and $\mathrm{N}$ levels on theyield and quality of French bean. P.K.V. Research Journal, 20, 174175.

[22] Tsai, S.M., Bonetti, R., Agbala, S.M. and Rossetto, R. (1993) Minimizing the effect of mineral nitrogen on biological nitrogen fixation in common bean by increasing nutrient levels. Plant and Soil, 152, 131-138. doi:10.1007/BF00016342 